\title{
INTRODUCTION
}

\section{De gevoelstemperatuur van het strafrecht}

\author{
Anne Ruth Mackor, Jeroen ten Voorde \& Pauline Westerman
}

In 2016 heeft een discussie over de koers van het NJLP geleid tot de breed gedragen beslissing om naast de special issues rond internationale rechtsfilosofen ook special issues over maatschappelijk relevante thema's te publiceren. Daarmee wordt aansluiting gezocht bij de rechtspraktijk in het Nederlands taalgebied. Voor $\mathrm{u}$ ligt het eerste special issue, dat is gewijd aan het maatschappelijk relevante thema 'de gevoelstemperatuur van het strafrecht'.

Vijf bijdragen in dit nummer vormen de schriftelijke neerslag van presentaties die op vrijdag 30 juni 2017 op de VWR Voorjaarsvergadering in Groningen zijn gehouden. In drie van deze presentaties staat - direct of indirect - de toegenomen aandacht voor slachtoffers centraal. Margreet Luth-Morgan (EUR) gaat in haar bijdrage in op de vraag of het voor het strafproces uitmaakt of de schuldgevoelens van de dader oprecht zijn en of in dat proces plaats is voor een ritueel van niet noodzakelijk oprechte verontschuldigingen. Vincent Geeraets en Wouter Veraart (beiden VU) bespreken de risico's van evidence-based onderzoek naar slachtoffers, dat vaak ook op rechtshervorming is gericht. De auteurs wijzen op de spanning tussen de versterking van de positie van het slachtoffer enerzijds en fundamentele rechtsbeginselen anderzijds. Ook Briain Jansen (EUR) waarschuwt voor een te grote nadruk op de rechten van slachtoffers. Hij bekritiseert het pleidooi van Klaas Rozemond tegen een strikte, wetshistorische, interpretatie van het strafrecht en - in navolging van Dworkin - voor een interpretatie in termen van rechten van slachtoffers. Jansen brengt daartegen in dat de rechten-benadering beter kan worden begrepen als een negatief ideaal, namelijk als een reden om het strafrecht niet toe te passen.

Het onderwerp van de andere twee presentaties ligt op het terrein van cybercrime; bij beide spelen computers en internet een sleutelrol. Jeroen ten Voorde (UL en RuG) bekritiseert de rechtvaardiging die de Nederlandse wetgever in termen van Mills schadebeginsel heeft gegeven voor de strafbaarstelling van virtuele grooming. Bij strafbaarstelling van seksueel getinte chats met virtuele minderjarigen dringt de vraag zich namelijk op of, en zo ja wie, geschaad wordt. Karel Harms (RuG) bespreekt het 'responsible disclosure'-beleid zoals dat door de Nederlandse overheid is ontwikkeld voor ethische hackers die ICT-kwetsbaarheden van organisaties op verantwoorde wijze willen melden. Ethisch hacken is in beginsel strafbaar (computervredebreuk, art. 138ab Sr), maar wordt door het overheidsbeleid gedoogd of zelfs aangemoedigd. Harms onderzoekt onder andere of dit beleid voldoet aan het Tallon-criterium, dat het uitlokken van strafbaar gedrag verbiedt. 
De andere zes presentaties die op de Voorjaarsvergadering in Groningen zijn gehouden, zijn niet in dit nummer opgenomen. De meeste zijn elders gepubliceerd. ${ }^{1}$ Deze voordrachten, met name die over het onderzoek naar de juridische status van oorlogsdoden en oorlogsgraven (Welmoet Wels, RuG) en de dubbele status van kindsoldaten als slachtoffer én dader (Suzanne Schot, RuG), maakten duidelijk dat de gevoelstemperatuur van het strafrecht niet alleen in nationaal, maar ook in internationaal strafrecht hoog is. Jannemieke Ouwerkerk (UL) ging in op de grondslagen van het EU-straf(proces)recht. De rechtshistorische beschouwing over het ontstaan van het 'moderne' strafrechtelijke bewijsrecht in de achttiende en negentiende eeuw (Ronnie Bloemberg, RuG) verhelderde onder meer (de aanleiding voor het verhitte debat over) het onderscheid tussen de conviction intime en de conviction raisonnée. Hoe hoog de gevoelstemperatuur van het strafrecht is, is de afgelopen vijftien jaar vooral ook gebleken uit de reacties op ernstige rechterlijke dwalingen, zoals onder andere in de Puttense moordzaak en de Schiedammer parkmoord. Modellen van rationeel bewijzen in het strafrecht (Henry Prakken, UU en RuG; Anne Ruth Mackor, RuG) beogen bij te dragen aan het voorkomen van bewijsrechtelijke dwalingen.

De zesde bijdrage aan dit special issue is gebaseerd op een workshop die werd gehouden op de VWR Wintervergadering op 3 februari 2017 in Utrecht. Deze bijdrage sluit echter naadloos aan bij het thema van de VWR Voorjaarsvergadering en dit eerste maatschappelijk relevante special issue. Als ergens blijkt dat de gevoelstemperatuur van het strafrecht is opgelopen, dan toch zeker in het 'minder-minder'-strafproces tegen Wilders, waar het artikel van Bert van Roermund (Tilburg Law School) aan is gewijd. Zijn bijdrage is een kritische beschouwing over de rol van de rechtsfilosoof - in deze rechtszaak was dat Paul Cliteur - als deskundige in rechtszaken.

1 Zie R.G. Bloemberg, 'De ontwikkeling van het moderne strafrechtelijke bewijsrecht in Nederland tussen 1750 en 1870,' te verschijnen in: Pro Memorie. Bijdragen tot de rechtsgeschiedenis der Nederlanden 19(2) (2017); A.R. Mackor, 'Novel Facts. The Relevance of Predictions in Criminal Law,' Strafblad (juni 2017): 145-56. De bijdrage van J.W. Ouwerkerk was gebaseerd op haar oratie Herijking van Uniestrafrecht. Over grondslagen voor strafrechtelijke regelgeving in de Europese Unie, gehouden op 7 april 2017 aan de Universiteit Leiden (Den Haag: Boom juridisch, 2017). Deze is online beschikbaar via: openaccess.leidenuniv.nl/bitstream/handle/1887/49439/HerijkingvanUniestrafrecht_auteurspdf.pdf?sequence=1. H. Prakken \& R. Meester, 'Bayesiaanse analyses van complexe strafzaken door getuige-deskundigen. Betrouwbaar en zo ja: nuttig?,' Expertise en Recht (5) (2017): 185-97. 